\title{
Activation Role of Low Dose Ionizing Radiation on Human Lymphocytes Response
}

\author{
S.A. Montaser", G.R. Abdel Hamid and A.R. Aboghadeer \\ Radiation Biology Department, National Centre for Radiation Research and \\ Technology (NCRRT), Atomic Energy Authority, Cairo, Egypt.
}

\begin{abstract}
T OW dose ionizing radiation can imitate the role of deteriorate antigen or attenuated microbes $U_{\text {as }}$ it activates the first defence line of immune response, the step which when lost, cancer cells can find suitable environmental condition for growth propagation. Human whole blood samples were irradiated in vitro at doses $(0.25,0.5,0.75$ and $1 \mathrm{~Gy})$ of ionizing radiation and then kept at $37^{\circ} \mathrm{C}$ for $1 \mathrm{~h}$ before measuring glucose concentrations which reflect the maximum activation of immune cells. Then, immunological parameters such as interlukine-1 $\beta$ (IL-1 $\beta$ ), interlukine-2 (IL-2), transforming growth factor beta (1) (TGF- $\beta 1$ ) were investigated. Also, inflammatory mediators as intracellular adhesion molecule (ICAM-1), vascular cell adhesion molecule (VCAM1) and tyrosine kinase activity were determined. Low doses of ionizing radiation induced slight activation of the immune cell cytokines (IL- $1 \beta$ and TGF- $\beta 1$ ), inflammatory mediators (ICAM, VCAM) and tyrosine kinase activity at doses $(0.25,0.5 \mathrm{~Gy})$ reaching to significant levels at $0.75 \mathrm{~Gy}$ and $1 \mathrm{~Gy}$. While, IL-2 and glucose levels were significantly decrease.
\end{abstract}

Keywords: Gmama-irradiation, IL-1 $\beta$, IL-2, TGF- $\beta$, ICAM and VCAM.

\section{Introduction}

Ionizing radiation has a variety of acute and longlasting adverse effects on the immune system. Whereas measureable effects of radiation on immune cell cytotoxicity and population change have been well studied in human and animal models, little is known about the functional alterations of the surviving immune cells after ionizing radiation. Not only activation of lymphocytes or macrophages, ionizing radiation also can help monocytes/macrophages in finding their targets through activation of their migration and chemotactic behaviour (Lauber et al., 2012).

Glucose uptake and consumption are markedly occurred through activation of $\mathrm{T}$ cells mainly during transcriptional regulation process (Wang et al., 2011). Also, Freemerman et al. (2014) stated that activation of lymphocytes is the most reason of glucose spending in immune system.

IL-1 $\beta$ and IL-2 are cytokines involved in early signaling and amplification of inflammatory responses, induction and activation of adhesion molecules, activation of local inflammatory response and regulatory functions of cytotoxic cells. Studies of low doses of radiation exposure, as in atomic radiation workers who occupationally exposed to 0.25 to $10 \mathrm{mGy}$ displayed stimulation of both cytokines receptors expression on the surface of peripheral blood lymphocytes taken from normal human donors (Guimbaud et al., 1998 and Xu et al., 1996).

In contrast, the secretion of the antiinflammatory cytokine TGF- $\beta$ was enhanced significantly after exposure of radiation at low doses (Rodel et al., 2012). This results in a down-regulation of leukocyte/peripheral blood mononuclear cells (PBMC) adhesion and may contribute to the anti-inflammatory effect of low dose radiotherapy (Roedel et al., 2002).

Tyrosine kinases play a central role in signal transduction, acting as relay points for a complex network of interdependent signalling molecules that ultimately affect gene transcription within the nucleus (Prenzel et al., 2001). Strict regulation of tyrosine kinases activity controls the most fundamental processes of cells, such as the cell cycle, proliferation, differentiation, motility and cell death or survival (Slichenmyer \& Fry, 2001). On the other hand, tyrosine kinase activity plays

"Corresponding author email: sherien_morsy@yahoo.com

DOI: 10.21608/ejrsa.2017.1816.1022

C2018 National Information and Documentation Center (NIDOC) 
a critical role in the modulation of growth factor signalling. Activated forms of these enzymes can cause increase in tumor cell proliferation and growth, induce antiapoptotic effects and promote angiogenesis and metastasis (Arora \& Scholar, 2005).

Mathias et al. (2015) studied the effects of irradiation on inflammatory/thrombotic plasma markers as ICAM-1 and VCAM-1. The study indicated that low irradiation doses (from $0.025 \mathrm{~Gy}$ ) induce local and systemic changes in an inflammatory-prone genotype. Thereby, high dose rates exerted more pronounced effects than low dose rates, although the general pattern of response was similar. Screening of 19 inflammation-related candidates revealed 11 markers including ICAM1 and VCAM-1 to be of high value to identify even small late effects of low-dose irradiation.

This study aims to discuss the ability to use low dose of ionizing radiation as a stimulatory factor to enhance the immune system activities and studying its effect on cytokines and tyrosine kinase production.

\section{Materials and Methods}

\section{Blood sampling}

Blood samples obtained from six healthy volunteers matched groups for ethnic background, sex, smoking and age were also investigated as control group.

All subjects were gave an informed consent for participation in this study. The donors were selected according to current International Programme on Chemical Safety (IPCS) guidelines.

Venous blood were collected under sterile conditions in heparinized vacationer tube $(\mathrm{v}=5$ $\mathrm{ml}$, Becton Dickinson, USA) containing Lithium heparin as anticoagulant.

\section{Irradiation source:}

${ }^{137} \mathrm{Cs} \gamma$-rays source was provided by the NCRRT, Egypt, manufactured by the Atomic Energy of Canada. The dose rate was $0.42 \mathrm{~Gy} /$ $\min$. The samples were kept for one hour at $37^{\circ} \mathrm{C}$ after irradiation till starting blood separation.

\section{Experimental design}

The blood from each volunteer was divided into five groups. One was non-exposed (control group) and the others were applied directly to $\gamma$-rays ionizing irradiation with doses $(0.25,0.50$, 0.75 and $1 \mathrm{~Gy}$ ). After ionizing irradiation exposure, the blood sample groups incubated at $37^{\circ} \mathrm{C}$ for $1 \mathrm{~h}$ before starting biochemical investigations.

\section{Determination of glucose concentration}

Glucose concentration measured according to the method described by Anastasovska et al. (2005)

Determination of $I L-1 \beta$, IL-2

Human IL-1 $\beta$ and IL-2 were measured according to the method described by Orgenium laboratories (IL- $1 \beta$ ELISA kit) from AviBion Human IL- $1 \beta$ ELISA.

\section{Determination of TGF- $\beta 1$}

TGF- $\beta 1$ was determined based on the sandwich principle using a TGF- $\beta 1$ enzyme-linked immunosorbant assay kit (DRG International, Inc.), according to the manufacturer's instructions.

Determination of inflammatory adherent molecules ICAM-1 \&VCAM-1

Human ICAM-1 and VCAM-1 in plasma were determined by using ELISA kits from My Bio Source.

\section{Determination of tyrosine kinase activity}

Human tyrosine kinase activity was determined by using ELISA kit purchased from SIGMA, ALDRICH for plasma.

\section{Statistical analysis}

The obtained data obtained are represented as mean \pm standard error. Statistical analysis was carried out using (Statistical Package for Social Science) (SPSS) software, significant differences among groups were evaluated using one-way analysis of variance (one-way ANOVA); least-significant difference (LSD) was used for multi-group comparisons. $\mathrm{P}$ values $\leq 0.05$ were considered as significant

\section{Results}

Table 1 showed significant reduction in glucose concentrations of all groups after $1 \mathrm{~h}$ in $37^{\circ} \mathrm{C}$ from irradiation. The most significant value noticed in $1 \mathrm{~Gy}$ group.

Table 2 recorded significant increase in IL-1 $\beta$ 
and TGF- $\beta 1$ levels for all groups, while significant reduction in IL-2 was scored.

Table 3 showed significant increase in both ICAM -1 and VCAM-1 concentration accompanied by increase in tyrosine kinase activity. The most increment value recorded at both 0.75 and 1 Gy doses. While, tyrosine kinase level recorded significant increases in its activity at all used doses $(0.25,0.5,0.75$ and $1 \mathrm{~Gy})$

TABLE 1. Glucose concentration in plasma of human blood samples exposed to different doses of ionizing radiation $(0.25,0.5,0.75$ and $1 G y)$.

\begin{tabular}{|c|c|c|c|c|c|}
\hline \multirow[b]{3}{*}{$\begin{array}{l}\text { Glucose } \\
\text { concentration }(\mu \mathrm{g} / \mathrm{L})\end{array}$} & \multicolumn{5}{|c|}{ Groups } \\
\hline & $\begin{array}{c}\text { Control group } \\
\mathrm{X} \pm \mathrm{SE} \\
\end{array}$ & $\begin{array}{c}\text { 0.25Gy group } \\
\mathrm{X} \pm \mathrm{SE}\end{array}$ & $\begin{array}{c}0.50 \mathrm{~Gy} \text { group } \\
\mathrm{X} \pm \mathrm{SE}\end{array}$ & $\begin{array}{c}\text { 0.75Gy group } \\
\mathrm{X} \pm \mathrm{SE}\end{array}$ & $\begin{array}{c}1 \mathrm{~Gy} \text { group } \\
\mathrm{X} \pm \mathrm{SE}\end{array}$ \\
\hline & $110.5 \pm 0.3$ & $70.9 \pm 0.3^{\mathrm{a}}$ & $65 \pm 0.4^{\mathrm{ab}}$ & $40.5 \pm 0.23^{\mathrm{abc}}$ & $36.8 \pm 1.2^{\mathrm{abc}}$ \\
\hline \multicolumn{6}{|c|}{$\begin{array}{l}\text { a significant with control. } \\
\text { b significant with } 0.25 \mathrm{~Gy} \\
{ }^{\mathrm{c}} \text { significant with } 0.50 \mathrm{~Gy} \\
\text { d significant with } 0.75 \mathrm{~Gy} \\
\text { Statistical significance value }(\mathrm{P} \leq 0.05) \text {. }\end{array}$} \\
\hline & \multicolumn{2}{|c|}{$\begin{array}{c}\text { Pro-inflammatory } \\
\text { cytokines }\end{array}$} & \multicolumn{2}{|c|}{ Regulatory cytokines } & \multirow{2}{*}{$\begin{array}{c}\text { TGF- } \beta 1(p g / m l) \\
X \pm S E\end{array}$} \\
\hline & \multicolumn{2}{|c|}{$\begin{array}{c}\text { IL-1 } \beta(p g / m l) \\
X \pm S E\end{array}$} & \multicolumn{2}{|c|}{$\begin{array}{c}\text { IL-2 }(\mathrm{pg} / \mathrm{ml}) \\
\mathrm{X} \pm \mathrm{SE}\end{array}$} & \\
\hline Control group & \multicolumn{2}{|c|}{$41.02 \pm 0.07$} & \multicolumn{2}{|c|}{$63.92 \pm 0.12$} & $51.3 \pm 0.34$ \\
\hline $0.25 \mathrm{~Gy}$ group & \multicolumn{2}{|c|}{$42.91 \pm 0.9^{\mathrm{a}}$} & \multicolumn{2}{|c|}{$60.33 \pm 0.59^{a}$} & $55.67 \pm 1.19^{\mathrm{a}}$ \\
\hline $0.5 \mathrm{~Gy}$ group & \multicolumn{2}{|c|}{$47.32 \pm 0.63^{\mathrm{ab}}$} & \multicolumn{2}{|c|}{$57.02 \pm 0.9^{\mathrm{ab}}$} & $62.13 \pm 0.91^{\mathrm{ab}}$ \\
\hline $0.75 \mathrm{~Gy}$ group & \multicolumn{2}{|c|}{$78.46 \pm 0.18^{\mathrm{abc}}$} & \multicolumn{2}{|c|}{$41.92 \pm 0.14^{\mathrm{abc}}$} & $89.27 \pm 0.67^{\mathrm{abc}}$ \\
\hline 1Gy group & \multicolumn{2}{|c|}{$80.0 \pm 0.32^{\mathrm{abcd}}$} & \multicolumn{2}{|c|}{$48.02 \pm 0.91^{\mathrm{abcd}}$} & $104.74 \pm 1.45^{\mathrm{abcd}}$ \\
\hline
\end{tabular}

a significant with control.

${ }^{\mathrm{b}}$ significant with $0.25 \mathrm{~Gy}$

${ }^{c}$ significant with $0.50 \mathrm{~Gy}$

d significant with $0.75 \mathrm{~Gy}$

Statistical significance value $(\mathrm{P} \leq 0.05)$.

TABLE 3. ICAM-1 and IVCAM-1 levels and tyrosine kinase activity in plasma of human blood samples exposed to different doses of ionizing radiation $(0.25,0.5,0.75$ and $1 \mathrm{~Gy})$.

\begin{tabular}{|c|c|c|c|}
\hline & \multicolumn{2}{|c|}{ Adhesion molecules } & \multirow{2}{*}{$\begin{array}{c}\text { Tyrosine kinase activity (pg/ml) } \\
\qquad \mathrm{X} \pm \mathrm{SE}\end{array}$} \\
\hline & $\begin{array}{c}\text { ICAM-1 (pg/ml) } \\
\text { X } \pm \text { SE }\end{array}$ & $\begin{array}{c}\text { VCAM-1 (ng/ml) } \\
\qquad \pm \pm \text { SE }\end{array}$ & \\
\hline Control group & $54.39 \pm 1.42$ & $65 \pm 1.15$ & $64.33 \pm 0.86$ \\
\hline $0.25 \mathrm{~Gy}$ group & $53.5 \pm 1.0$ & $63.33 \pm 0.95$ & $68.61 \pm 0.83^{\mathrm{a}}$ \\
\hline 0.75Gy group & $83.7 \pm 0.42^{\mathrm{abc}}$ & $97.68 \pm 3.05^{\mathrm{abc}}$ & $87.04 \pm 0.15^{\mathrm{abc}}$ \\
\hline 1Gy group & $98.6 \pm 1.2^{\mathrm{abcd}}$ & $109.83 \pm 3.9^{\mathrm{abcd}}$ & $95.44 \pm 1.08^{\mathrm{abcd}}$ \\
\hline
\end{tabular}

a significant with control.

${ }^{\mathrm{b}}$ significant with $0.25 \mathrm{~Gy}$

${ }^{c}$ significant with $0.50 \mathrm{~Gy}$

${ }^{\mathrm{d}}$ significant with $0.75 \mathrm{~Gy}$

Statistical significance value $(\mathrm{P} \leq 0.05)$. 


\section{Discussion:}

It is well known that high doses of ionizing radiation can cause cancer and current regulation of radiation risk is based on the linear no-threshold model which states that even the tiniest dose of radiation will increase your cancer risk. However, it is now an undisputed fact that low doses of radiation $(<100 \mathrm{mGy})$ cause different biological responses to that of high doses. Considerable data have also accumulated demonstrating that low doses of ionizing radiation can stimulate mechanisms that can prevent or delay cancer formation. The latter data have been published over many years for many biological endpoints and provide insights into potential new approaches for cancer prevention and treatment, and yet are largely ignored. The current model of radiation risk assessment and the depiction of radiation exposure in the media contribute to radiation phobia in the general public and also in health professionals. Data will be presented to place low doses of radiation into perspective and to highlight the potential of harnessing low dose biological responses for health benefits (Sykes, 2012).

The present study focused on the effects of radiation exposure at doses less than $1 \mathrm{~Gy}$ to stimulate mechanisms that can defend biological systems against cancer and other immunological defects through the chosen parameters.

Many types of immunological and blood cells are preferentially metabolize glucose as an energy substrate and exhibit a Warburg-like shift (high rate of glycolysis) in cellular metabolism upon activation (Krawczyk et al., 2010; Maciver et al., 2008 and Vats et al., 2006). And this interpreted the obtained results showed in Table 1 which reflected reduction in glucose concentrations of all groups after one hour in $37^{\circ} \mathrm{C}$ from irradiation. Freemerman et al. (2014) stated that the reduction of glucose concentration in group which exposed to $0.75 \mathrm{~Gy}$ may be attributed to consumption of glucose due to activation of lymphocytes.

Several studies showed that low irradiation doses (from $0.025 \mathrm{~Gy}$ ) induced local and systemic changes in an inflammatory-prone genotype. Thereby, high dose rates exerted more pronounced effects than low dose rates, although the general pattern of response was similar. Screening of several inflammation-related candidates revealed 11 effective markers (MCP-1, TNF, TGF, ICAM-
1, VCAM-1, and fibrinogen, Thy1, collagen IV, CD31) to be of high value to identify even small late effects of low-dose irradiation (Mathias et al., 2015). In that context, the current study investigates some of these markers as (IL-1 $\beta$, IL-2, TGF- $\beta 1$, ICAM-1, VCAM-1and tyrosine kinase) with different low doses of irradiation $(0.25,0.50$, 0.75 and $1 \mathrm{~Gy})$.

Macrophages and mast cells are tissue-resident cells and are frequently the first dedicated immune cells to detect the presence of a pathogen. Both of these cell types have an important role in sensing infection and in amplifying immune responses, through the production of cytokines (interleukins), chemokines and other soluble mediators (such as vasoactive amines and lipids) that have effects on local endothelium and facilitate the migration of other immune cells (such as neutrophils) to the site of an infection through recruitment of latter from the blood (Delves et al., 2017).

In addition, Gasteiger \& Kastenmuller (2015) confirmed that radiation exposure stimulate IL-2 receptors expression in a large population of peripheral blood lymphocytes and this shows a triggered-type response rather than being proportional to dose. Also, they demonstrate that normal human cells can respond to doses of radiation in the range of common occupational or medical exposures.

Moreover, low-dose irradiation between 0.3 and $0.7 \mathrm{~Gy}$ induced a relative maximum of TGF- $\beta$ production by stimulated endothelial cells and results in a down-regulation of leukocyte adhesion and may contribute to the anti-inflammatory effect of low dose radiotherapy (Roedel et al., 2002).

Our results recorded significant increase in IL$1 \beta$ and TGF- $\beta 1$ levels in all groups and these finding could be attributed according to the pervious facts, although significant reduction in IL-2 was scored and interpreted by Chen et al. (2011) and Pandiyan et al. (2011) who discussed the restricting IL-2 during acute infection might additionally enhance immunity and regeneration.

Low radiation doses $(0.025-0.5 \mathrm{~Gy})$ induce adaptive late responses through the enhancement of adherent molecules as ICAM-1 and VCAM-1 expressions which indicate a pro-inflammatory response (Mathias et al., 2015). These conclusions coincide with our results pointed in Table 3 . 
On the other hand, tyrosine kinase activity plays a critical role in the modulation of growth factor signaling. Activated forms of these enzymes can cause increase in tumor cell proliferation and growth, induce antiapoptotic effects and promote angiogenesis and metastasis. In addition to activation by growth factors, protein kinase activation by somatic mutation is a common mechanism of tumor genesis. Because all of these effects are initiated by receptor tyrosine kinase activation, they are key targets for inhibitors (Arora \& Scholar, 2005).

Table 3 demonstrated that tyrosine kinase level recorded significant increases in its activity at all used doses $(0.25,0.5,0.75$ and $1 \mathrm{~Gy})$ but these increment levels activate the immunological cells and its processes without proliferation interruption as occurred by high doses exposure. Slichenmyer \& Fry (2001) and Vala et al. (2010) confirmed these findings through their work on doses $\leq 0.8 \mathrm{~Gy}$ which enhance cell migration without impinging on cell proliferation or survival. In addition, low-dose of ionizing radiation induces a rapid phosphorlylation of several cell proteins, including growth factor receptors.

Moreover, tyrosine kinases play a central role in signal transduction, acting as relay points for a complex network of interdependent signaling molecules that ultimately affect gene transcription within the nucleus (Prenzel et al., 2001).

\section{Conclusion}

Ionizing radiation has different biological effects according to dose and dose rate. In particular, the biological effect of low-dose radiation is unclear. Low-dose of gamma irradiation activates immune responses in several ways. Low dose ionizing radiation can imitate the role of deteriorate antigen or attenuated microbes as it initiate first defense line of immune response, the step which when lost cancer cells can find suitable environmental condition for growth propagation.

\section{Conflict of interest}

The authors declare that: There is no conflict of interest.

\section{Funding sources}

Our research did not receive any specific grant from funding agencies in the public, commercial, or not-for-profit sectors.
Acknowledgment: The authors greatly appreciate Dr. Mahmoud Refaat Ahmed Mohamed (Air Force Hospital) for his help, in blood sampling.

\section{References}

Anastasovska,V., Dosić-Markovska, B., Stojkovski, V. and Dimitrova-Sumkovska, J. (2005) Erythrocyte glucose-6-phosphate dehydrogenase activity in laboratory rats treated with amoxiclav, lidaprim and 1-chloro-2,4-dinitrobenzen. Prilozi, 26(1), 121-31.

Arora, A. and Scholar, E.M. (2005) Role of tyrosin kinase inhibitors in cancer therapy. The Journal of Pharmacology and Experimental Therapeutics, 315(3), 971-979.

Chen, Y., Haines, C.J., Gutcher, I., Hochweller, K., Blumenschein, W.M., McClanahan, T., Hammerling, G., Li, M.O., Cua, D.J. and McGeachy, M.J. (2011) Foxp3(+) regulatory $\mathrm{T}$ cells promote $\mathrm{T}$ helper 17 cell development in vivo through regulation of interleukin-2. Immunity, 34(3), 409-421.

Delves, P.J., Martin, S.J., Burton, D.R. and Roitt, I.M. (2017) Innate immunology. "ROITT s' Essential Immunology", $13^{\text {th }}$ ed. John Wily \& Sons Ltd. Southern Gate, Oxford, UK.

Freemerman, A.J., Johnson, A.R., Sacks, G.N., Milner, J.J., Kirk, E.L. and Troester, M.A. et al. (2014) Metabolic reprogramming of macrophages: Glucose transporter 1 (GLUT1)-mediated glucose metabolism drives a proinflammatory phenotype. Journal of Biological Chemistry, 289(11), 78847896.

Gasteiger, G. and Kastenmuller, W. (2015) Foxp3+ Regulatory T-cells and IL-2: The Moirai of T-cell Fates? Frontiers in Immunology, 3, 179-183.

Guimbaud, R., Bertrand, V., Chauvelot-Moachon, L., Quartier, G., Vidon, N., Giroud, J.P., Couturier, D. and Chaussade, S. (1998) Network of inflammatory cytokines and correlation with disease activity in ulcerative colitis. The Amirican Journal of Gastroenterology, 93(12), 2397-404.

Krawczyk, C.M., Holowka, T., Sun, J., Blagih, J., Amiel, E., DeBerardinis, R.J., Cross, J.R., Jung, E., Thompson, C.B., Jones, R.G. and Pearce, E.J. (2010) Toll-like receptor-induced changes in glycolytic metabolism regulate dendritic cell activation. Blood, 115(23), 4742-9. 
Lauber, K., Ernst, A., Orth, M., Herrmann, M. and Belka, C. (2012) Dying cell clearance and its impact on the outcome of tumor radiotherapy. Frontiers Oncology, 2, 116-130.

Maciver, N.J., Jacobs, S.R., Wieman, H.L., Wofford, J.A., Coloff, J.L. and Rathmell, J.C. (2008) Glucose metabolism in lymphocytes is a regulated process with significant effects on immune cell function and survival. Journal of Leukocyte Biology, 84(4), 949957.

Mathias, D., Mitchel, R.E., Barclay, M., Bugden M., Priest, N.D., Whitman, S.C., Scholz, M., Hildebrandt, G., Kamprad, M. and Glasow, A. (2015) Low-dose irradiation affects expression of inflammatory markers in the heart of ApoE -/- mice. PLOS One, 11(6), 1-14.

Pandiyan, P., Conti, H.R., Zheng, L., Peterson, A.C., Mathern, D.R., Hernandez-Santos, N., Edgerton, M., Gaffen, S.L. and Lenardo, M.J. (2011) CD4(+) CD25(+) Foxp3(+) regulatory $\mathrm{T}$ cells promote Th17 cells in vitro and enhance host resistance in mouse Candida albicans Th17 cell infection model. Immunity, 34(3), 422-434.

Prenzel, N., Fischer, O.M. and Streit, S. et al. (2001) the epidermal growth factor receptor family as a central element for cellular signal transduction and diversification. Endocrine - Related Cancer, 8(3), 11-31.

Rodel, F., Frey, B. and Manda, K. et al. (2012) Immunomodulatory properties and molecular effects in inflammatory diseases of low- dose X-irradiation. Frontiers Oncology, 2(120), 1-9.

Roedel, F., Kley, N., Beuscher, H.U., Hildebrandt, G., Keilholz, L., Kern, P., Voll, R., Herrmann, M. and Sauer, R. (2002) Anti-inflammatory effect of low-dose X-irradiation and the involvement of a TGF-beta1-induced down-regulation of leukocyte/ endothelial cell adhesion. International Journal Radiation Biology, 78(8), 711-719.

Sykes, J.P. (2012) The benefits of low dose radiation and the hazards of the media. Supplement, 44(1),1-4.

Slichenmyer, W.J. and Fry, D.W. (2001) Anticancer therapy targeting the erbB family of receptor tyrosine kinases. Seminars Oncology, 28(16), 67-79.

Vala, S., Martins, L.R., Imaizumi, N., Nunes, R.J., Rino, J., Kuonen, F., Carvalho, L.M., Rüegg, C., Grillo, I.M., Barata, J.T., Mareel, M. and Santos, S.C. (2010) Low doses of ionizing radiation promote tumor growth and metastasis by enhancing angiogenesis. PLoS One, 5(6), 67-79.

Vats, D., Mukundan, L., Odegaard, J.I., Zhang, L., Smith, K.L., Morel, C.R., Wagner, R.A., Greaves, D.R., Murray, P.J. and Chawla, A. (2006) Oxidative metabolism and PGC-1 attenuate macrophagemediated inflammation. Cell Metabolism, 4(1), 1324.

Wang, R., Dillon, C.P., Shi, L.Z., Milasta, S., Carter, R. and Finkelstein, D. et al. (2011) The transcription factor Myc controls metabolic reprogramming upon T lymphocyte activation. Immunity, 35(6), 871-882.

Xu, Y., Greenstock, C.L., Trivedi, A. and Mitchel, E.J. (1996) Occupational levels of radiation exposure induce surface expression of interleukin-2 receptors in stimulated human peripheral blood lymphocytes. Radiation and Environmental Biophysics, 35(2), 8993.

(Received 10/ 10/2017; accepted 13/11/2017) 


\section{الدور المنشط للجرعات المنخفضة من الأشعاعات المؤينة على استجابة الخلايا الليمفاوية

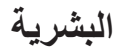

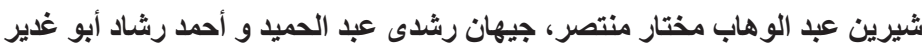 قسم بحوث البيولوجيا الأشعاعية ـ المركز القومى لبحوث وتكنولو لوجيا الأشعاع- هيئة الطاقة الذرية ـ القاهرة ـ}

تم تعرض خلايا الدم البشرية إلى جرعات منذفضة مختلفة من الأشعاع المؤين وهى (0.25 و0.50.0.5و 0.75)

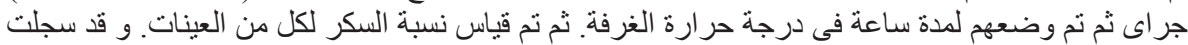
النتائج جميعا إنخفاضا ملحوظا فى جميع العينات ولكن الإنخفاض الأكثر سجل عند التعرض الترن اللجر عة (0.75) جراى.

وقد أنخذ نقص مستوى السكر فى الام كعلامة مميزة لنشاط الخالايا الليمفاوية واستهلاكها لنسبة السكر الموجودة بالدم لافر از العديد من الأنترلوكينات و وسيطات الخلايا التى تسهل التواصل بلين التين الخلايا المختلفة.

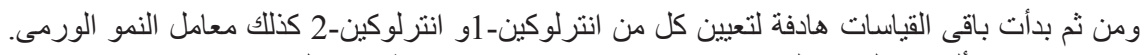

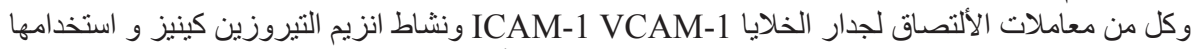

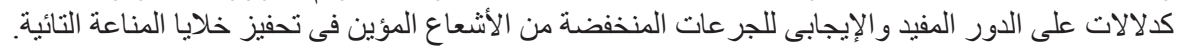

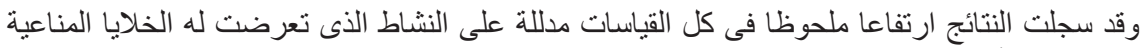
و الدور المحفز للأشعة المؤينة فى الجر عات المنخفضة والجر عة المختارة (0.75) جراى. 